\title{
New Late Devonian phacopid trilobites from Marhouma, SW Algerian Sahara
}

\author{
RAIMUND FEIST, ABDESSAMED MAHBOUBI \& CATHERINE GIRARD
}

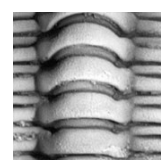

\begin{abstract}
Late Devonian phacopid trilobites of the SW Algerian Sahara are recognised as being the most diversified in cratonic North Gondwana. The first trilobites in the Frasnian of Algeria were discovered in the Marhouma S section near Beni Abbes: the new genus Chlupacops with two species Ch. laticeps gen. et sp. nov. and Ch. aff. cryphoides (Richter \& Richter) are described from the uppermost part of the Cheffar el Ahmar Formation of mid-Frasnian age. The latter taxon is compared with the type material of Ch. cryphoides (Richter \& Richter) from Sessacker (Rhenish Slate Mts). New occurrences of lower Famennian phacopids in the "Argiles de Marhouma" Formation comprise the new genus Enigmapyge with its type species E. marhoumensis gen. et sp. nov., two species of Trimerocephalus: T. mahboubii sp. nov. and T. caecus (Gürich), two species of Trifoliops: Tr. cronierae sp. nov. and Tr. trifolius (Osmólska). In the middle Famennian, pygidia of Dianops cf. algeriensis Crônier were discovered. With the exception of the latter all taxa of the Marhouma S section can be assigned to conodont zones. The Algerian Late Devonian phacopids comprise predominantly blind or reduced-eyed taxa of basinal offshore environment. They are closely related to contemporaneous occurrences on the epicontinental margins of Laurussia as well as in Gondwana derived terranes and as such bear witness of the absence of oceanic barriers. $•$ Key words: phacopid trilobites, Late Devonian, SW Algerian Sahara, stratigraphy, taxonomy, environment.
\end{abstract}

FEIST, R., MAHBOUBI, A. \& GIRARD, C. 2016. New Late Devonian phacopid trilobites from Marhouma, SW Algerian Sahara. Bulletin of Geosciences 91(2), 243-259 (5 figures). Czech Geological Survey, Prague. ISSN 1214-1119. Manuscript received December 20, 2015; accepted in revised form April 12, 2016; published online May 26, 2016; issued June 30, 2016.

Raimund Feist (corresponding author), Abdessamed Mahboubi \& Catherine Girard, Institut des Sciences de l'Evolution, Université Montpellier II, UMR 5554 of CNRS, 34095 Montpellier Cedex 05, France; raimund.feist@univ-montp2.fr

The first comprehensive study on Late Devonian phacopids in SW Algeria was recently carried out by Crônier et al. (2013). They concerned Famennian occurrences in several localities of the Saoura Valley. Our contribution aims to complete Crônier et al.'s work by further phacopid records in the lower part of the Famennian. In addition, Frasnian phacopids are presented for the first time from this region. Field work focused on the region south of Marhouma village (Marhouma S section, Fig. 1) in the frame of conodont based biostratigraphical and sedimentological investigations in the Frasnian and Lower Famennian (Mahboubi 2015, doctorate thesis; Mahboubi \& Gatovski 2015 and Mahboubi et al. 2015).

\section{Location, stratigraphy and trilobite record}

The Marhouma S section is situated S of the SW Algerian Saoura Valley, at $17 \mathrm{~km}$ SE of Beni Abbes township, at about $13 \mathrm{~km} \mathrm{SW}$ of Marhouma village and at $3.3 \mathrm{~km}$ WNW of "km 30" section (Fig. 1). The Middle Devonian of the "km 30" section belonging to the Cheffar el Ahmar Formation (Boumendjel et al. 1997) was measured and investigated for goniatites and conodonts by Göddertz (1987). The top of this section (in Göddertz 1987, bed 78, p. 202) with Ancyrodella lobata Branson \& Mehl, 1934 is already of Middle Frasnian age and it correlates with bed MH9 of our Marhouma S section further to the W (Fig. 2). This marker bed is characterised by numerous goniatites Mesobeloceras Glenister, 1958 covering the surface of the bedding plane. It is included in a series of alternating dark shales and solid pseudo-nodular bioclastic limestone beds of deep water outer ramp environment that characterise the uppermost $20 \mathrm{~m}$ of the Cheffar el Ahmar Formation with conodonts of MN Zones 5 to 8 (Mahboubi \& Gatovsky 2015). The first known Frasnian trilobites of the Saoura region, i.e. Chlupacops laticeps gen. and sp. nov. and Ch. aff. cryphoides (Richter \& Richter, 1926), occur in limestone beds MN7 and MN13 respectively (locality 1, Fig. 2, $\mathrm{N} 29^{\circ} 57^{\prime} 31.6^{\prime \prime}, \mathrm{W} 2^{\circ} 06^{\prime} 07.8^{\prime}$ ). In the superseding "Argiles 
de Marhouma" Formation, which totals up to 260 m (Ouali Mehadji et al. 2012) the Frasnian part did not provide any determinable trilobites. In contrast loose ferruginous nodular cephalopod limestone concretions in shale matrix (beds MH 40-46) of early rhomboidea age with Palmatolepis rhomboidea Sannemann, 1955 and Icriodus olivierii Corradini, 1998 yield well preserved specimens of Trimerocephalus mahboubii sp. nov., Trifoliops trifolius Osmólska, 1958, Trifoliops cronierae sp. nov. and Enigmapyge marhoumensis gen. et sp. nov. (locality 2, N 29 57' 37.6", W $2^{\circ} 06^{\prime} 10.9^{\prime \prime}$ ). Equivalent levels ("Argiles de Mahouma" Formation, member 2, Crônier et al. 2013, p. 1004) revealed the presence of Houseops? cryphoides (Richter \& Richter, 1926), T.? (Trifoliops) sp., Trimerocephalus (Trifoliops) nigritus Crônier, 2003, and Trimerocephalus caecus (Gürich, 1896), the latter two discovered in the S Marhouma area. A single juvenile specimen of Trimerocephalus caecus occurs in the body chamber of Praemeroceras Becker, 1993 in fish-bearing reddish "griotte" limestones

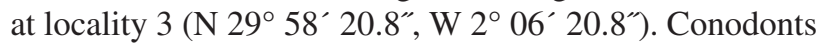
from this level (Palmatolepis gracilis gracilis, P. quadrantinodosa inflexoidea) indicate the Lower marginifera Zone. Crônier et al. (2013) determined Phacops tamtertensis from an equivalent level in section Tamtert-Zereg further to the East. In the upper part of the "Argiles de Marhouma" Formation specimens of Dianops cf. algeriensis Crônier et al., 2013 occur in shaly marlstones at locality 4 (N 29 $57^{\prime} 56.4^{\prime \prime}, \mathrm{W} 2^{\circ} 04^{\prime} 08.8^{\prime \prime}$ ) that did not provide any conodonts. After Crônier et al. (2013) these levels (Member $3 \mathrm{c}$ of the "Argiles de Marhouma" Formation) belong to the Famennian IV according to clymeniids. Dianops algeriensis Crônier et al., 2013, D. vicarius Chlupáč, 1961, D. typhlops (Gürich, 1896), Phacops zeregensis Crônier et $a l ., 2013$ of middle to late Famennian age were described by Crônier et al. (2013) from the Zereg area.

\section{Systematic palaeontology (R. Feist)}

Terminology follows Whittington \& Kelly (1997) and Holloway (2005). Additionally, the portion between the anterior facial suture and the anterior edge of the vincular furrow is referred to "pre-vincular doublure"; likewise the portion between the posterior edge of the vincular furrow and the hypostomal suture is referred to "post-vincular doublure". Figured and additional material is deposited in the collections of University Montpellier 2 (UM2-IP 712-727) and in the Senckenberg Museum Frankfurt (SMF).

Family Phacopidae Hawle \& Corda, 1847

Subfamily Phacopinae Hawle \& Corda, 1847

\section{Genus Chlupacops gen. nov.}

Type species. - Chlupacops laticeps gen. et sp. nov.

Etymology. - After Ivo Chlupáč (Prague) in recognition of his fundamental work on phacopid trilobites.

Species assigned. - Chlupacops laticeps sp. nov., middle Frasnian, Algeria; Phacops cryphoides Richter \& Richter, 1926, middle-?late Frasnian, Germany; Chlupacops aff. cryphoides (Richter \& Richter, 1926), middle Frasnian, Algeria. Assigned with question: Phacops (Phacops) cf. cryphoides Richter \& Richter, 1926 (in Matern 1927), early Famennian, Germany; Houseops? cf. cryphoides (Richter \& Richter, 1926) (in Crônier et al. 2013), early Famennian, Algeria. Phacops (Phacops?) reichi Kegel, 1931, Givetian, Germany; Phacops koeneni Holzapfel, 1895, Givetian, Germany; Nephranops? spectabilis Meischner, 1965, Givetian, Germany.

Diagnosis. - Wide, transversely low vaulted cephalon with short, wide-based, anterior-ward protruding glabella; small forward positioned eye with reniform visual surface; deeply marked, outwardly concave palpebral furrows and narrow palpebral lobes; deep vincular structure and long post-vincular doublure; pygidium trapezoidal, of high lateral and transverse profile; pygidial axis narrow, high, arched in lateral profile, with few axial rings; sculpture: fine-grained dense tuberculation.

Stratigraphical range. - Late Givetian (?), Frasnian, early Famennian (?).

Occurrence. - SW Algeria (Marhouma region), Morocco (Oulmès region), Germany (Rhenish Slate Mts: Sessacker; Thuringia: Schleiz, Saalfeld).

Remarks. - Frasnian phacopids with forwardly shifted small eye-lobes were questionably assigned to Houseops (Feist et al., 2009). These are now reassigned to the new genus mainly on account of the shorter, rather wide-based anterior glabella and the different configuration of the eye-lobe that is generally shorter, and has a deeper, outwardly concave palpebral furrow. Some traits of the new genus such as the advanced eye-lobe, wide and short anterior glabella lobe and fine-grained sculpture are similarly developed in Phacops koeneni and Nephranops? spectabilis. These poorly known latest mid-Devonian taxa were assigned to Chotecops Chlupáč, 1971 by Chlupáč (1971) and to Phacops s.l. by Basse (1998). Richter \& Richter (1955, p. 57) suggested possible phyletic relationships between koeneni and cryphoides. Awaiting revision after recovery of sufficiently well preserved material these forms might reveal their closer relationship to the new genus to which 


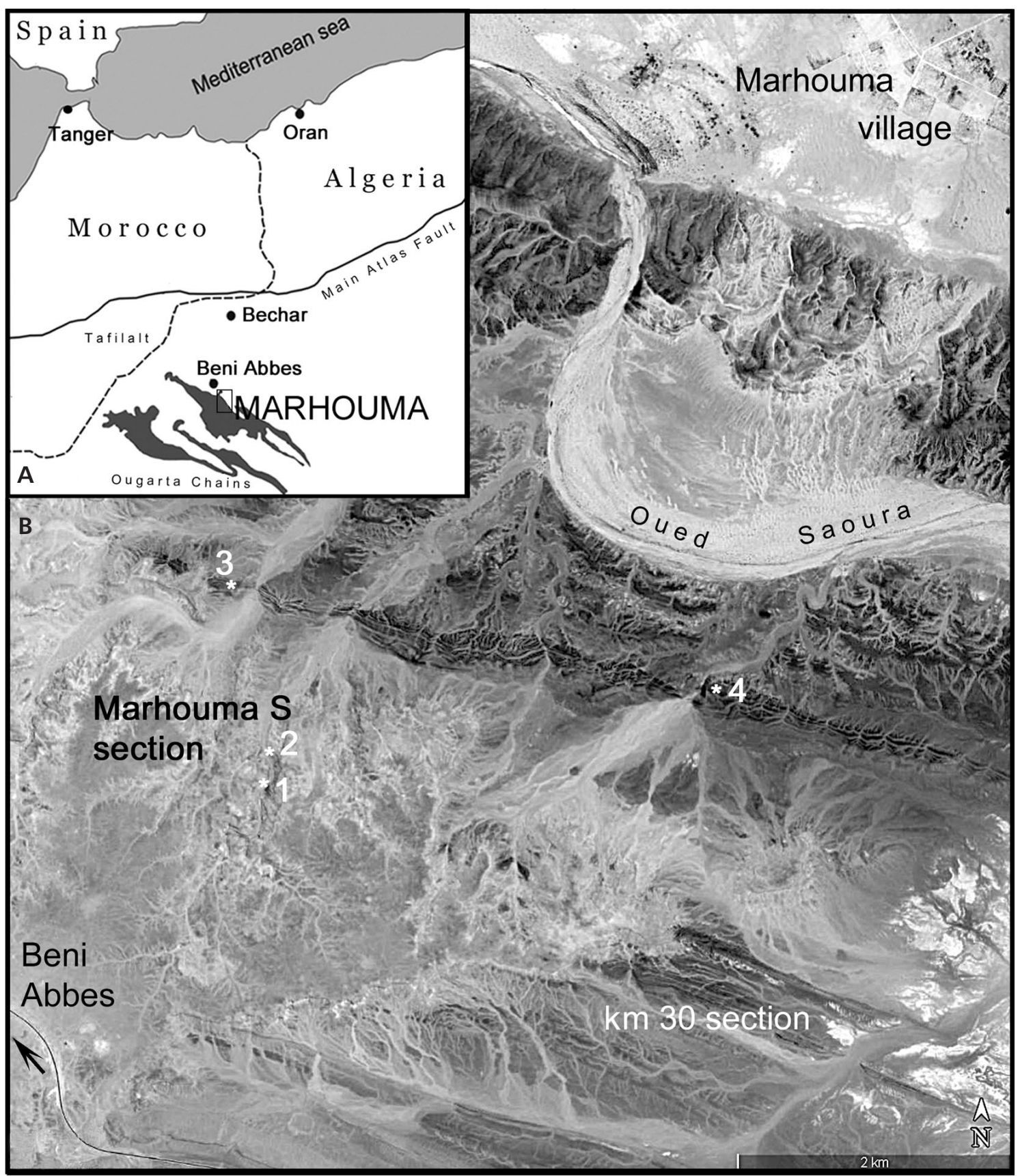

Figure 1. Geographic location of studied trilobite sites in the Marhouma area. $\bullet$ A - situation of the Marhouma area in the northern Ougarta Chains, SW Algeria. $\bullet$ B - Google Earth satellite view of the area SW of Marhouma village showing the position of four trilobite sites in the Marhouma S section between Saoura valley and asphalt road to Beni Abbes.

they are tentatively assigned here. Another similar Givetian taxon, Phacops (Phacops?) reichi was attributed to Phacops (Kegelops) subgen. nov. by Alberti (1970, p. $160-$ nomen nudum), followed by Basse (1998, p. 14). Subsequently this taxon was questionably assigned to Eocryphops Richter \& Richter, 1931 by Alberti (1983), followed by Holloway (2005) who enumerated a considerable amount of particular traits that concern the eye-lobe and the configuration of L1. Some of these traits along with the position of the eye-lobe that does not extend beyond the lateral border furrow in dorsal view, the much lower transverse vault of the cephalon with rather wide lateral borders, and the fine-grained tuberculation are all typical characters of Chlupacops gen. nov. In consequence, the tentative assignment of reichi to the new genus rather than to Eocryphops is preferred. 
Chlupacops laticeps sp. nov. Figure $3 \mathrm{~A}-\mathrm{H}$

Holotype. - Complete exoskeleton in Salter's position, UM-IP 712, Fig. 3A-E.

Etymology. - After the transversely wide cephalon.

Type horizon. - Upper part of Cheffar el Ahmar Formation, Frasnian, MN Zone 5/6.

Type locality. - Locality 1, Marhouma S section, SW Algeria.

Material. - Holotype specimen UM-IP 712; paratype: 1 pygidium UM-IP 713, both from locality 1, bed MH 7 .

Diagnosis. - Very wide cephalon with evenly curved anterior outline, narrow sunken L1 with minute, swollen, ovoid lateral nodes, eye-lobe lower than posterior genal field, encroaching onto lateral border, distally short genal field (exsag.). Pygidium long trapezoidal with high axis of strongly curved lateral profile.

Description. - Cephalon twice as wide as long. Composite glabellar lobe wide and short, length 0.6 of width; anterior outline parabolic, slightly protruding medially, laterally defined by straight, deep axial furrows diverging in an angle of $68^{\circ}$; anterior corners sub-angular; base slightly recessed medially, sharply and continuously separated from L1 by deep slightly sinuous S1. Glabellar furrows $\mathrm{S} 2$ and S3 inconspicuously impressed, hardly distinguishable by lack of sculpture. L1 unobtrusive, very narrow, in middle part deeply sunken below levels of occipital lobe and composite glabella, with minute, swollen, ovoid lateral nodes. Occipital lobe long, robust, without median tubercle, expanding forwards medially and separated from L1 by marked, slightly curved occipital furrow, abruptly narrowing distally behind long (exsag.) deeply impressed occipital apodemes. Genal field small, sub-triangular, moderately swollen adaxially, lesser distally, markedly circumscribed by combined, invariably deep and continuous posterior and lateral border furrows of parabolic course in genal angle. Genal field does not expand forward abaxially being intersected by posterior part of furrow surrounding base of visual surface such that no anterior stripe of genal field remains below and outside eye-lobe ( $c f$. Fig. 3E). Eye lobe prominent, very small, elliptical in outline in dorsal view, circumscribed by deep furrows comprising adaxially con- vex palpebral furrow and outward-curved furrow below visual surface; long axes of elliptical eye-lobes diverge from another by $48^{\circ}$; distance between posterior end of eye lobe and posterior border furrow (exsag.) is greater than the length of the eye-lobe (1:0.9). Palpebral lobes slightly inclined adaxially, small, with two pits in its outer part, bordered by palpebral rims, delimited by outward-curved palpebral suture. Lateral borders slightly vaulted in cross section, expanding towards genal angle, widest opposite posterior border furrow, slowly tapering forward to disappear below frontal lobe of glabella shortly inside to its corners. Transverse profile of cephalon is very low in anterior view, height of glabellar lobe equals one third of total width of cephalon and half width of glabellar lobe. Visual surfaces of eye-lobes slope with $45^{\circ}$. In lateral view, frontal glabellar lobe rather high, down-curved, protruding and a little expanding beyond pre-frontal furrow; anterior border short, moderately vaulted; anterior edge of vincular furrow a little higher than posterior, the latter being backwardly positioned; median profile of composite glabella lobe evenly curved, of moderate vault, more strongly down-turned behind; L1 deep-set; occipital lobe inflated, lower than composite glabellar lobe. In lateral view, height of eye lobe equals height of adjacent antero-lateral border, remaining considerably below glabella. Base of eye lobe slightly encroaching onto antero-lateral border and deviating the course of the lateral border furrow. Visual surface kidney-shaped with 15 lenses in irregular 6-7 vertical rows with a maximum of 3 lenses in a row. Ventrally, post-vincular doublure flat, horizontal, 2.7 times longer than vincular furrow (sag.). Vincular furrow evenly curved, deep, of even width medially and abaxially, delimited by sharp edges. Pre-vincular part of doublure equals length of vincular furrow (sag.). Thoracic axial rings provided with lateral lobes; axis moderately high. Pygidium longer than half width (length $=0.67$ of width), sub-pentagonal with evenly rounded posterior outline. Articulating anterior edge between axial furrow and fulcrum is half in length of oblique antero-lateral edge. Projection of maximum width lies opposite to $6^{\text {th }}$ axial ring. Posterior edge raises medially in posterior view. Outer pleural regions of strong declivity. Axis high, narrower (tr.) than pleural region, of continuously curved lateral profile until merger with postaxial region, not reaching posterior edge. Straight, moderately tapering axial furrows fading away around posterior tip. There are $7+1$ straight axial rings. Inter-ring furrows straight, deeper impressed distally than medially. Weak pseudo-articulating half rings on second and third axial ring. Pleural region with 4 pleural ribs, moderately vaulted

Figure 2. Marhouma S columnar section with lithology and conodont biostratigraphy of the uppermost Cheffar el Ahmar Formation and the lower and middle "Argiles de Marhouma" Formation with positions of trilobite sites (after Mahboubi \& Gatovsky 2015, modified). Arrow: Mesobeloceras marker bed. 
Raimund Feist et al. • New Late Devonian phacopid trilobites from Marhouma, SW Algerian Sahara

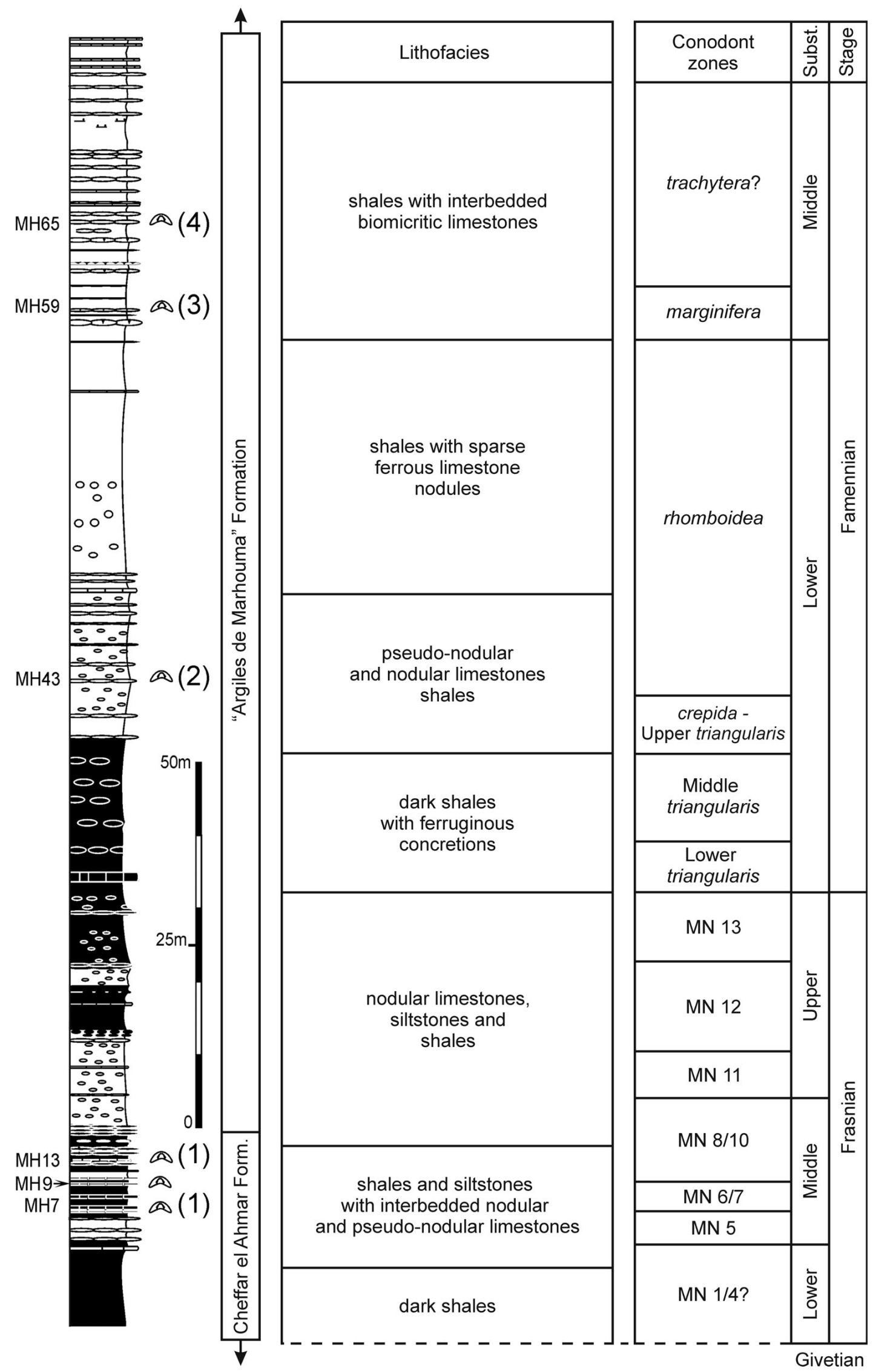


in section, separated by deeply impressed pleural furrows that die out beyond inner two thirds of pleural region. Postero-lateral edges framed with tiny rim. Sculpture: very dense, fine tuberculation on entire exoskeleton.

Remarks. - The new species resembles the Givetian Chlupacops? reichi in the shape of its transversely wide composite glabellar lobe, deeply sunken L1, and fine tuberculation. It is distinct from reichi by the presence of inflated lateral nodes on L1 and a narrow though sunken median ridge of L1. Its eye is kidney-shaped and has many more lenses (15 versus 7). In reichi, unlike laticeps, the eye lobe remains distant from the lateral border furrow.

\section{Chlupacops cryphoides (Richter \& Richter, 1926)} Figure 3P-S

v. 1926 Phacops (Phacops) cryphoides n. sp.; Richter \& Richter 1926, p. 257, pl. 12, figs 41, 42.

non 1931 Phacops (Phacops) cryphoides. - Matern 1931, p. 106 (= cf. cryphoides).

1956 Phacops (Phacops) cryphoides. - Müller, p. 21.

1959 Phacops (Phacops) cryphoides. - Pfeiffer, pp. 269-270, pl. 3, figs 2-4.

1994 Phacops cryphoides. - Feist \& Schindler, p. 204.

2003 Phacops (Phacops) cryphoides. - Weyer et al., p. 74.

2007 "Phacops" cf. cryphoides. - Kaiser et al., p. 239.

2009 Houseops? cryphoides. - Feist et al., pp. 14-15.

New material. - Fragmentary cephalon (SMF 96457) with eye lobe from type locality Sessacker (Germany), bed 1, trench VI (Feist \& Schindler 1994, p. 3).

Remarks. - Revision of Richter \& Richter' originals (SMF 570 a-d) reveals the holotype cephalon being a juvenile holaspid. Adult-sized morphs among these originals (i.e. two specimens (SMF 570a and c) along with a newly discovered specimen figured here (Fig. 3P-S) exhibit a much wider base of the composite glabella lobe. This character, in addition to the small advanced eye with kidney-shaped visual surface and the fine-grained, dense tuberculation al- low integrating cryphoides and allies into the new genus Chlupacops. In comparison with the juvenile holotype, adult specimens have a greater visual surface with more lenses (27 versus 18). In contrast to laticeps, the base of the eye-lobe reaches the lateral border furrow only with it's anterior tip allowing forward expansion of the distal genal field below and adjacent to the furrow at base of visual surface. The prominent tubercles on the anterior border and on the anterior prolongation of the genal field below the eye that characterise the juvenile holotype, have vanished in adults where merely irregular nodes and grooves are perceptible. The originals were found in middle Famennian toI $\gamma$ strata at Sessacker; our new specimen from Sessacker trench VI occurs below the Lower Kellwasser horizon and is probably of late jamiae age, thus in accordance with Richter \& Richter's assignment of the species to the late middle Frasnian. However, the occurrence of cryphoides below the Upper Kellwasser horizon at Schleiz (Müller 1956) points to the extension of its range to the late Frasnian.

Houseops? cf. cryphoides (in Crônier et al. 2013, p. 1019 , figs $3 \mathrm{~m}-\mathrm{r}, 4 \mathrm{~b}$ ) has an anteriorly roof-shaped profile of the frontal lobe and as such is markedly more pointed in front than cryphoides. The ocular lobe is more backwardly positioned and does not reach the antero-lateral border furrow in front of it, where a small concave stripe of the anterior librigenal field remains. The divergence of the axial furrows is moderate $\left(64^{\circ}\right.$ versus $\left.68^{\circ}\right)$ in cryphoides and aff. cryphoides of similar size (it is $78^{\circ}$ in the young holaspid specimen of cryphoides). The anterior corners of the glabella are slightly truncated in contrast to those of cryphoides. The palpebral lobe is wider than in cryphoides specimen of equivalent size. The visual surface is more steeply inclined with fewer lenses (21 versus 27) than in cryphoides where the palpebral portion of the facial suture tends to become rectilinear in adults (it is more outwardly convex in the juvenile holotype specimen). However the base of the preoccipital glabella is rather wide transversely and this character excludes its assignment to Houseops. The Algerian taxon occurs in the lower Famennian and may be conspecific with Matern's (1927) fragmentary specimen from the Lower Famennian of Sessacker ("Phacops cf. cryphoides", Senckenberg 710a).

Figure 3. A-H - Chlupacops laticeps gen. et sp. nov., upper part of the Cheffar el Ahmar Formation, Frasnian, MN Zone 5/6, locality 1, Marhouma S section, SW Algeria. • A-E - holotype, entire carapace in Salter's position (A); dorsal (B), ventral (C), anterior (D) and lateral (E) views of cephalon, UM-IP 712. • F-H - pygidium, dorsal (F), posterior (G) and lateral (H) views, UM-IP 713. • I-O - Chlupacops aff. cryphoides (Richter \& Richter, 1926), upper part of the Cheffar el Ahmar Formation, Frasnian, MN Zone 8/10, locality 1, Marhouma S section, SW Algeria. • I - lateral view of cephalon, UM-IP 715. • J, L, N, O - entire, enrolled specimen, partly exfoliated, lateral (J), dorsal (L) views of pygidium, dorsal view of fragmentary cephalon (N), anterior view of cephalon and posterior view of pygidium (O), UM-IP 714. $\bullet \mathrm{K}, \mathrm{M}$ - cephalon, partly exfoliated and abraded, dorsal (K), ventral (M) views, UM-IP 716. P P-S - Chlupacops cryphoides (Richter \& Richter, 1926), Sessacker trench VI, Frasnian, Oberscheld, Rhenish Slate Mts, Germany. $\bullet \mathrm{P}, \mathrm{S}$ - cephalon, latex cast, lateral (P) and dorsal (S) views, SMF-RX 570c. $\bullet \mathrm{Q}$ - cephalon, plaster cast, anterior view, SMF-RX 570a. $\bullet$ R - fragmentary cephalon, dorsal view, SMF 96457. Scale bars represent $2 \mathrm{~mm}$. 

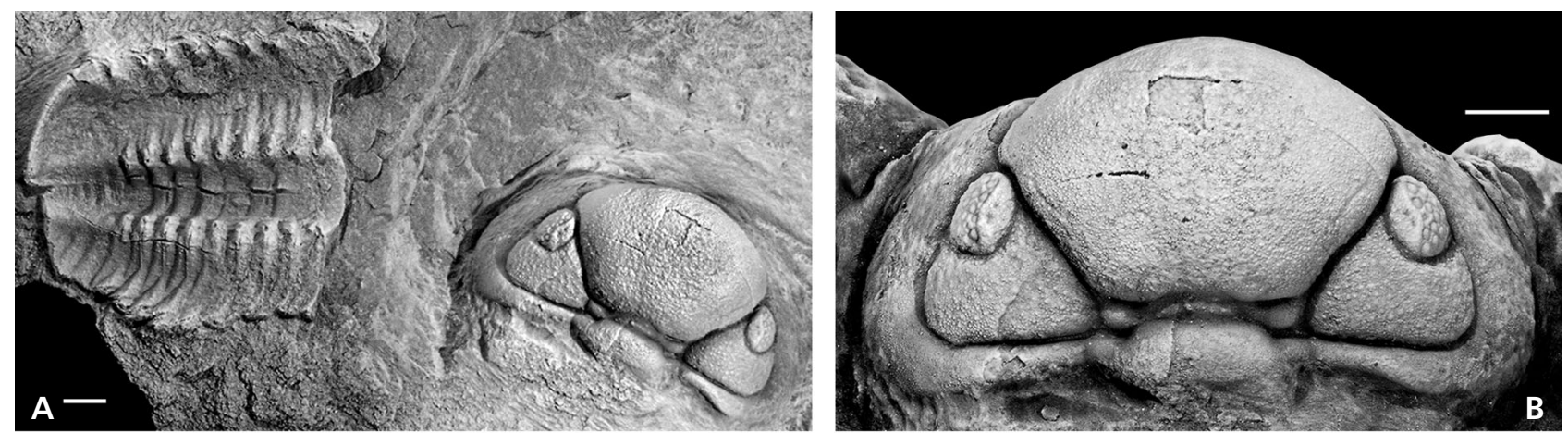
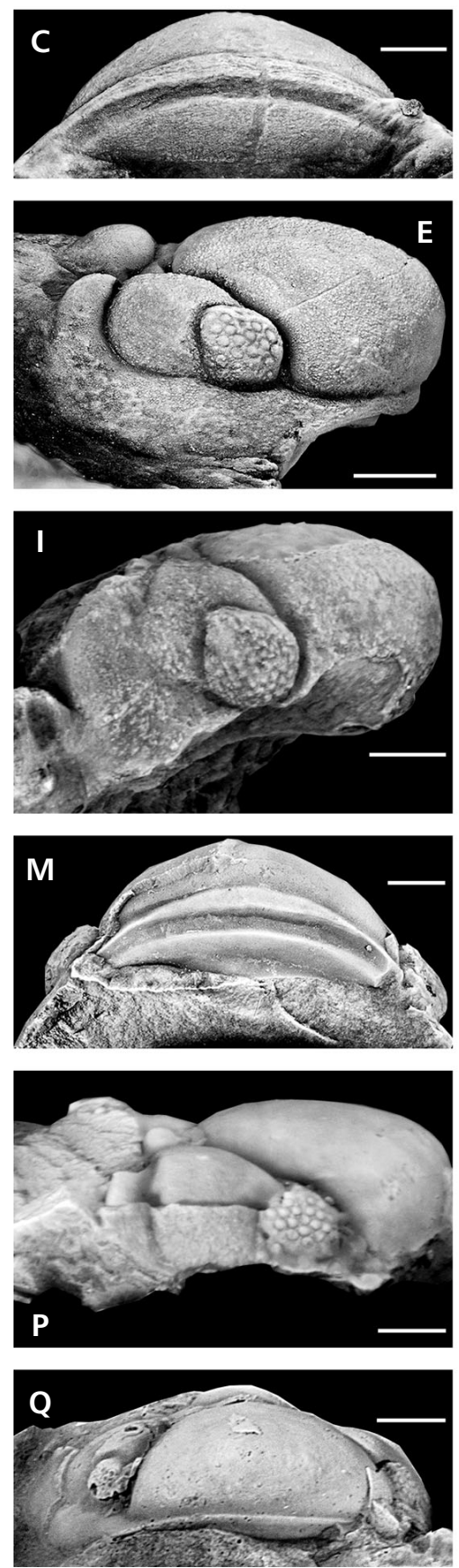
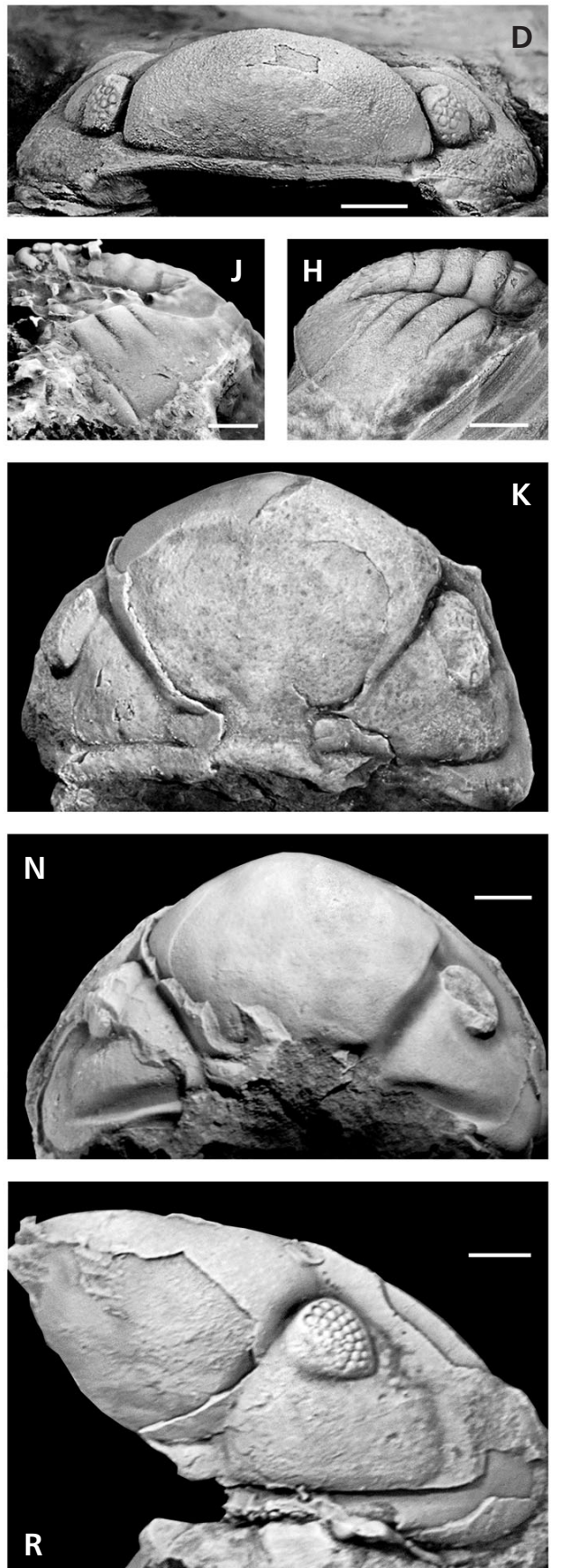
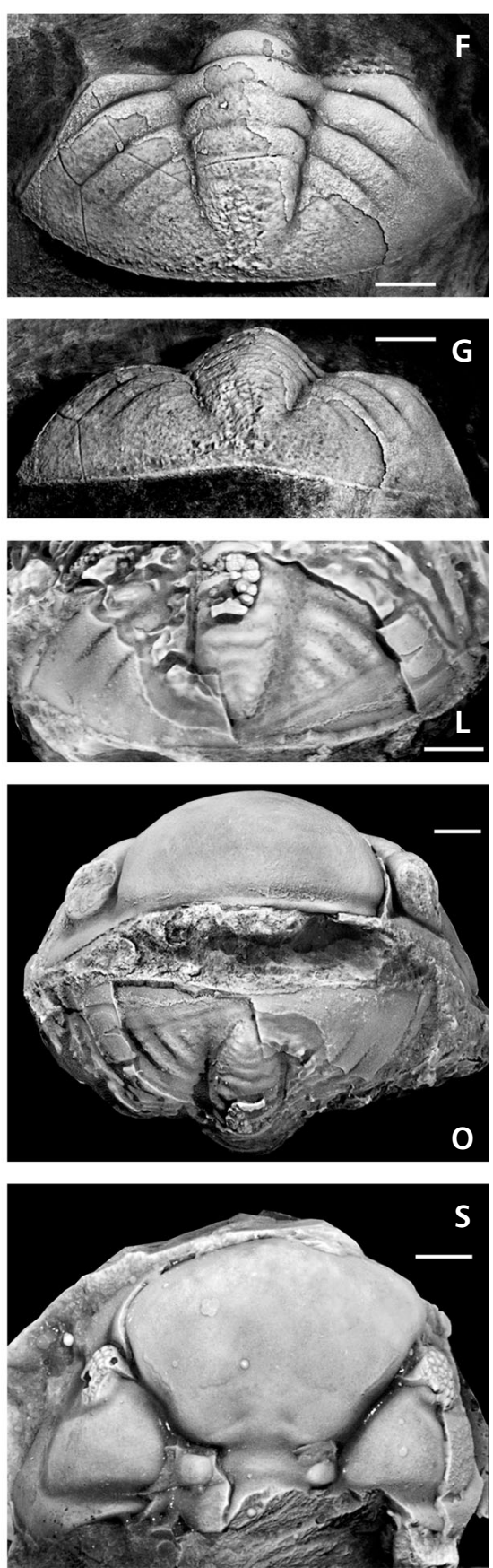
It may constitute a new species of Chlupacops gen. nov. but more and better preserved material is needed to assess the assignment.

\section{Chlupacops aff. cryphoides (Richter \& Richter, 1926) Figure 3I-O}

Material. - Entire, enrolled exoskeleton, UM-IP 714, 3 fragmentary cephala, UM-IP 715-717, all from locality 1, bed MH 13, Zone MN 8/10, middle Frasnian.

Remarks. - The poorly preserved, partially abraded material does not allow determination at species level. It is closely related to Chlupacops cryphoides sharing the general outline and shape of the composite glabellar lobe that is slightly pointed in front, and the configuration of L1, especially the large, quadrangular, moderately inflated lateral nodes. The latter distinguish both cryphoides and aff. cryphoides from laticeps where L1 is much narrower and lower. The eye in aff. cryphoides is higher and less distant from the posterior border furrow than in cryphoides and in laticeps. Its visual surface carries the same number of lenses (27 lenses in 11 rows with max. 4 lenses in a row) in comparison to adult sized specimens of cryphoides, but the latter has only 8 rows of lenses). In contrast, the base of the eye lobe encroaches onto the lateral border as seen in laticeps. The post-vincular doublure is shorter (sag.) and upward turned behind whereas it is longer and flat in both $l a-$ ticeps and cryphoides. Whereas the pygidium of the latter remains unknown, it is characterised, in aff. cryphoides, by its rather narrow axis and the length/width ratio of its outline (0.45) which is much lower than in laticeps. According to its many differential traits it is likely that aff. cryphoides represents a new species but better preserved material is needed to assess the diagnosis with confidence.

\section{Genus Trimerocephalus McCoy, 1849}

Type species. - Phacops mastophthalmus Richter, 1856; Gattendorf, Thuringian Slate Mountains, Germany, Early Famennian Cheiloceras Stufe.

Species assigned. - Trimerocephalus caecus (Gürich, 1896), Famennian II-III, Algeria, Brittany, Rhenish Slate Mts, Harz Mts, Thuringia, Holy Cross Mts, Urals; T. chopini Kin \& Błażejowski, 2013, II, Holy Cross Mts; T. cryptophthalmoides (Maksimova, 1955), II, Urals, Kazakhstan; T. dianopsoides Osmólska, 1963, II?-III, Holy Cross Mts; T. interruptus Berkowski, 1991, III, Holy Cross Mts; T. lacunosus (Pfeiffer, 1959), II, Thuringia; T. lelievrei Crônier \& Feist, 1997, II, Tafilalt; T. lentiginosus (Maksimova, 1955), V, Urals; T. mastophthalmus (Richter, 1856),
II, England, Rhenish Slate Mts, Harz Mts, Thuringia, Holy Cross Mts, Asia minor, Kazakhstan; T. mahboubii sp. nov., II, SW Algeria; T. mimbi Feist et al., 2009, II, Canning Basin; T. polonicus Osmólska, 1958, III, Holy Cross Mts; T. procurvus Arbizu, 1985, III, Cantabrian Mts; T. shotoriensis Feist in Feist et al., 2003, II-III, Iran; T. sponsor Chlupáč, 1966, III, Moravia, Cantabrian Mts; T. tardispinosus Feist \& Becker, 1997, II, Canning Basin; T. vodorezovi (Maksimova, 1955), II, Kazakhstan. Species assigned with question: T.? steinachensis (Richter \& Richter, 1926), II, Harz Mts, Thuringia.

\section{Trimerocephalus mahboubii sp. nov.}

Figure 4A-K

Holotype. - Entire articulated exoskeleton, UM-IP 718, Fig. 4A, E-I.

Etymology. - In acknowledgement of Mohamed Mahboubi (University of Oran), who provided invaluable field assistance and hospitality.

Type horizon. - Shale with calcareous concretions of the "Argiles de Marhouma" Formation (member 2a of Crônier et al. 2013), Early rhomboidea Zone.

Type locality. - Marhouma S section, locality 2, South of Marhouma village at $25 \mathrm{~km} \mathrm{~W}$ of Beni Abbes, SW Algeria.

Material. - Holotype specimen UM-IP 718, paratypes: two cephalothoraces (UM-IP 719-720) from type locality 2.

Diagnosis. - Very close to the type species with following distinct features: S1 interrupted medially; lateral nodes of L1 prominent, rectangular, completely separated from median part by deep furrows, extending backward at the expense of occipital ring; occipital furrow slightly curved forward medially with angular retreat behind lateral nodes of L1; occipital ring transverse sub-rectangular with concave posterior edge parallel to occipital furrow. Curvature of lateral border furrow slightly truncated opposite to genal angle. Pleural ribs of pygidium faint.

Description. - Anterior outline of cephalon semi-elliptical; width $/$ length ratio $=1.6$, width $/$ height ratio $=2.3$. Profile of preoccipital glabella continuously and moderately vaulted, slightly overhanging in front. Profile of anterior border (= previncular doublure) backward directed, not prominent but rather in continuation with frontal curvature of glabella (sag.). In frontal view, anterior border furrow containing facial suture remains horizontal and homogenously deeply incised. Previncular doublure slightly enlarged medially (sag.). In ventral view vincular furrow rather deep, evenly 

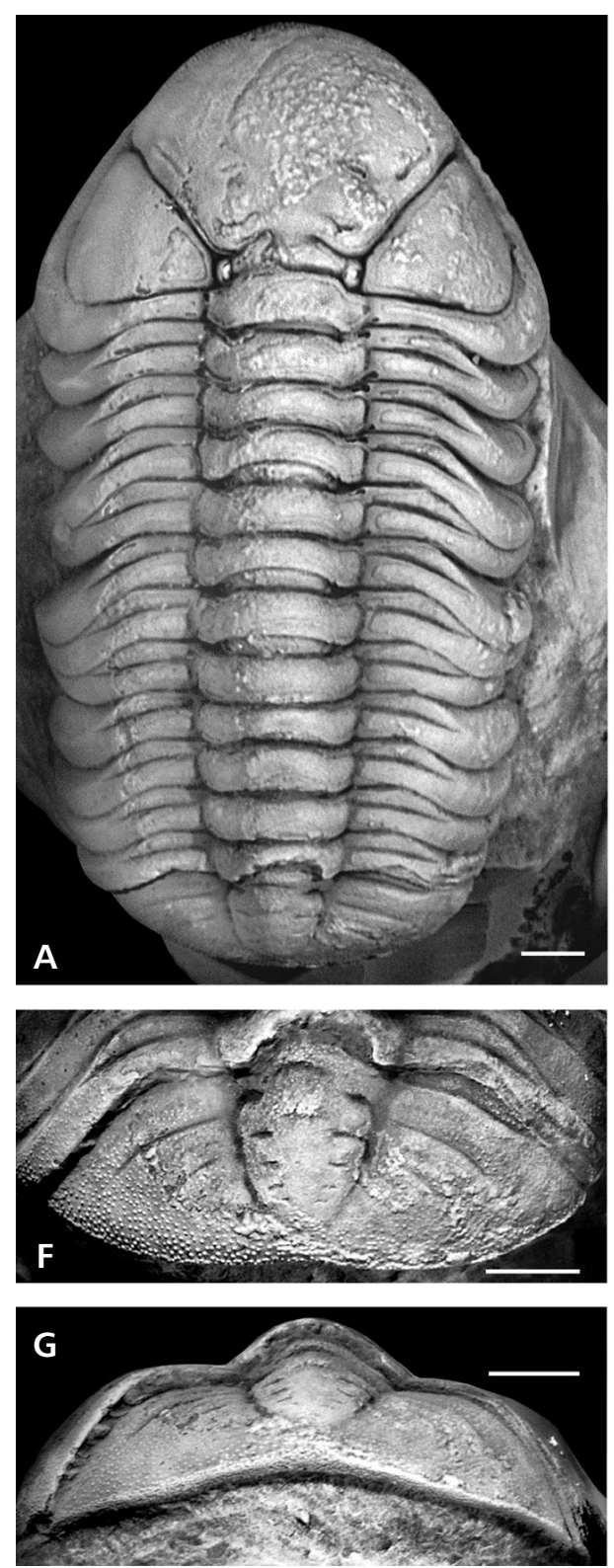
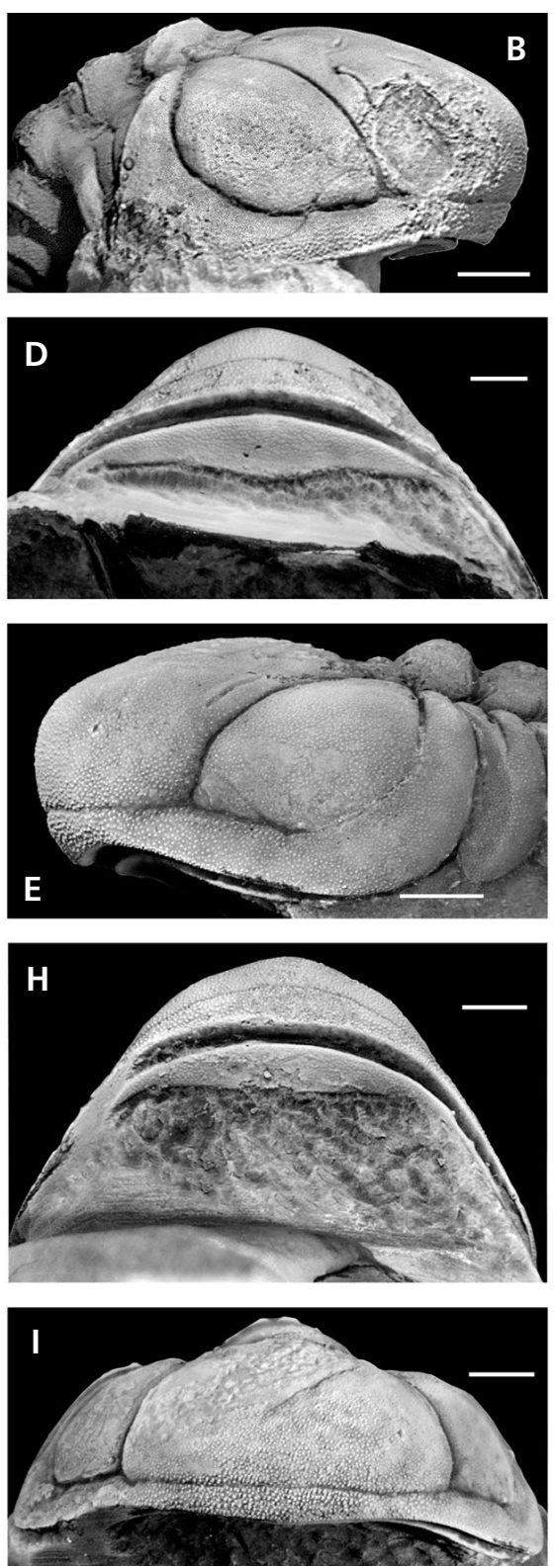
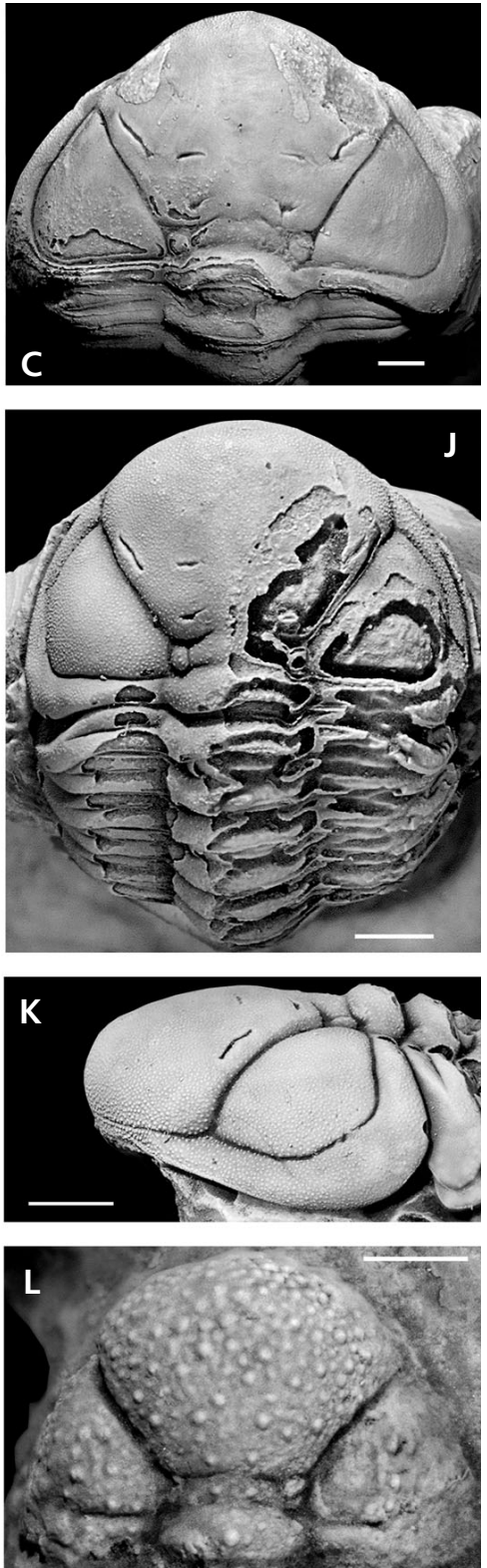

Figure 4. A-K - Trimerocephalus mahboubii sp. nov., "Argiles de Marhouma” Formation, member 2a of Crônier et al. (2013), lower rhomboidea Zone, locality 2, Marhouma S section, SW Algeria. • A, E-I - holotype, dorsal view of entire articulated carapace (A); lateral (E), ventral (H), anterior (I) views of cephalon; dorsal (F) and posterior (I) views of pygidium, UM-IP 718. • B-D - lateral (B), dorsal (C) and ventral (D) views of cephalon, UM-IP 719. • J, K - dorsal (J) and lateral (K) views of cephalothorax, UM-IP 720. • L - Trimerocephalus caecus (Gürich, 1896), Marhouma Formation, member 2 b of Crônier et al. (2013), upper rhomboidea Zone, locality 3, Marhouma S section, SW Algeria, dorsal view of juvenile cephalon, UM-IP 721. Scale bars represent $2 \mathrm{~mm}$ except for $\mathrm{L}$, which represents $1 \mathrm{~mm}$.

curved (tr.) below glabella, defined by anterior and posterior borders of equal height. Postvincular doublure horizontal, flat, equivalent in length to previncular doublure (sag.), with straight hypostomal suture (in holotype). Axial furrows of straight divergence ( $78^{\circ}$ in holotype). Anterior glabellar furrows short, deeply impressed. Distal parts of $\mathrm{S} 1$ rising from deep apodemes when directed forwards adaxially before abruptly vanishing. Median part of S1 is a very shallow sinuous depression between L1 and compo- site glabella lobe. L1 slightly curved, enlarged medially (sag.), and slightly vaulted in section. Individualised lateral nodes rather prominent, of rectangular outline, clearly delimited from median part of L1 by marked longitudinal furrows (exsag.) that run from S1 to occipital furrow. Lateral nodes of L1 extend to the rear at the expense of the distal occipital lobe. Occipital furrow continuously deep and slightly forward-curved, angular in its course when abruptly stepping backwards distally to meet deep occipital 
apodemes. Occipital ring long (sag.), wider than L1 (tr.), sub-rectangular, semi-cylindrical in section, higher than adjacent glabella, only insignificantly reduced in length at its distal ends (exsag.). Posterior edge of occipital ring parallel to occipital furrow. Genal field inflated, more so posteriorly than antero-laterally, surrounded by continuously well marked posterior and lateral border furrows, the latter being slightly truncated laterally opposite to forward shifted genal angle. Lateral border considerably enlarged and slightly inflated at genal angle. In dorsal view antero-lateral border disappearing below frontal lobe of glabella shortly after junction of border and axial furrows. Facial suture on genal field crescent-shaped. Anterior genal field, adjacent to and immediately behind facial suture, slightly swollen. Sculpture: dense granulation throughout. Thorax with 11 segments, a robust axis and pleurae of even width; nine anterior axial rings equivalent to each other, the remaining last ones a little narrower (tr.); axial rings slightly turned forwards distally without narrowing (exsag.); length of facets equal to $3 / 4$ of total pleural length (tr.). Pygidium lens-like with a width/length (without articulating half-ring) ratio equals 2.7. Axis slender, low, vaguely pointed behind, $76 \%$ of width of pleural region (tr.), with five flat axial rings, slightly eroded medially, with laterally straight, deep apodeme impressions of which only the anterior two reach axial furrow. Second axial ring with pseudo-articulating half-ring, projected forwards to the expense of first ring. Terminal piece twice as long as last axial ring (sag.). Axial furrows slightly curved, fading away behind. Axis does not reach edge of posterior margin. Pleural region evenly vaulted (sag. and tr.) without border furrow and border. Pleural field with three (four?) low pleural ribs of even width (exsag.) with marked pleural furrows and shorter, faint interpleural furrows that die out far before reaching postero-lateral edge of pleural field. Posterior margin with slight median incursion, thickened and roof-like upraised in posterior view. Sculpture: dense tuberculation.

Remarks. - Our material comprises holaspid specimens of different sizes in which few non-diagnostic characters differ. The smallest specimen (Fig. 4J, K) that reaches $75 \%$ of cephalic length of the holotype has a lesser divergence of axial furrows $\left(67^{\circ}\right.$ versus $\left.78^{\circ}\right)$, and a distally more rounded anterior outline of frontal glabella. The largest specimen (Fig. 4B-D) that reaches $117 \%$ of cephalic length of the holotype has an even more reduced divergence of axial furrows $\left(62^{\circ}\right)$ and a different outline of the hypostomal suture that extends backwards medially. More material is needed to decide whether these traits are within the limits of morphological variation or, in contrast, are characteristic of a distinct species.

Comparisons. - The new species is closest related to the type species T. mastophthalmus in all general features of the exoskeleton, notably the shape of the glabella and cheeks as well as in the course of the facial suture. It differs significantly in the configuration of L1 with its individualised, prominent lateral nodes as well as in the course of S1 and preoccipital furrows. Indeed, in all figured samples of T. mastophthalmus, i.e. Pfeiffer (1954, Thuringia), Maksimova (1955, Urals), Osmólska (1958, Holy Cross Mts), Lütke (1968, Harz Mts), Becker \& Schreiber (1994, Rhenish Slate Mts) S1 shallows medially but is not interrupted, and the lateral nodes of L1 are less prominent and not separated from the median part. In the new species, the occipital ring remains longer (exsag.) abaxially and as such appears more robust and rectangular. The truncated postero-lateral course of the border furrow in the cephalon is not seen in the type species but it occurs likewise in the contemporaneous T. shotoriensis; however, the latter is distinguished by a different configuration of the facial suture. The pygidium is nearly identical with $T$. mastophthalmus in its outline but has a weaker relief of the pleural ribs. In contrast to the well-preserved pygidia of T. mastophthalmus from the Harz Mountains (Lütke 1968, pl. 8, figs 5,7 ) the axis of the new species is narrower, slender and pointed behind, and the posterior outline is truncated medially.

\section{Trimerocephalus caecus (Gürich, 1896)} Figure 4L

2013 Trimerocephalus caecus. - Crônier et al., p. 1011, fig. $3 \mathrm{a}-\mathrm{c}$. See previous synonymies here.

New material. - One juvenile cephalon, UM-IP 721, from body chamber of Praemeroceras sp. (det. R.T. Becker), "Argiles de Marhouma" Formation, member 3b of Crônier et al. 2013, Lower marginifera Zone, Late early Famennian, locality 3 .

Remarks. - The specimen clearly exhibits the characteristic features of the species, i.e. median node on occipital ring, a pair of marked nodes on intercalating ring, and tubercles of different sizes on the entire cephalon. However, the frontal outline of the glabella is less pointed medially than in the adult specimen from the same region figured by Crônier et al. (2013).

\section{Genus Trifoliops Crônier, 2003}

Type species. - Dianops? trifolius Osmólska, 1958 ; Kadzielnia, Holy Cross Mountains, Poland, Early Famennian Cheiloceras Stufe.

Species assigned. - Trifoliops trifolius (Osmólska, 1958), 
Famennian II, Holy Cross Mts, SW Algeria, Montagne Noire; T. nigritus Crônier, 2003, II-III, Montagne Noire, SW Algeria; T. cronierae sp. nov., II, SW Algeria.

Remarks. - In agreement with Chlupáč (1977) and Crônier (2003), I consider trifolius and allies not being assigned to the genus Trimerocephalus mainly on account of different synapomorphic characters such as the embayment of the antero-lateral cephalic borders and the long (sag., exsag.) vincular furrow. In consequence, generic status of Trifoliops Crônier, 2003 is preferred.

\section{Trifoliops trifolius (Osmólska, 1958)} Figure 5F-I

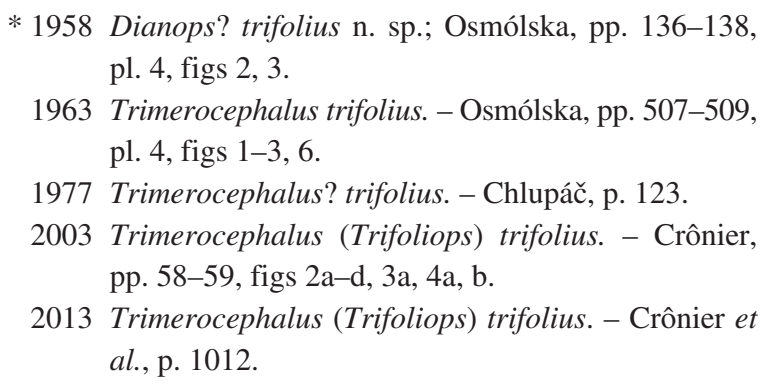

New material. - One cephalon, UM-IP 722, 1 thoracopygon, UM-IP 723 slightly dislocated from cephalon on the same slab, from ferruginous concretions of the "Argiles de Marhouma" Formation (member 2a of Crônier et al. 2013), Early rhomboidea Zone.

Remarks. - The pygidium of the polish material of T. trifolius is poorly known; only the internal view of the reversed thoraco-pygon of an entire specimen in Salter's position from the type locality Kadzielnia was figured (Osmólska 1963). This pygidium does not show details of axial rings and pleural field. The pygidium from Algeria matches the general form and dimensions of Osmólska's specimen and the axis has a similar outline and length; it can be assigned to $T$. trifolius with confidence. The well-preserved pygidium from Marhouma is lens-shaped with a width/length (without articulating half-ring) ratio of 2.2 and an evenly rounded posterior outline without margin. The position of the maximum width lies at the posterior fourth of pygidial length (without articulating half ring). The axis is moderately high, with a continuously transverse vault, and is slightly flattened behind with a straight descending lateral profile. It carries 6 prominent axial rings that form forward-curved bands of constant length (sag., exsag.) medially to distally. The first axial ring is markedly wider (tr.) than the others. The triangular, rearwards pointed end-piece that may contain 2 further rudimentary rings equalizing the combined length (sag.) of the two last axial rings. All axial rings are well defined by continuously wide, deep inter-ring furrows of which the three anterior ones meet the axial furrows shortly after deepening distally. The well-marked axial furrows converge stronger besides the first axial ring, taper slightly thereafter until the $5^{\text {th }}$ axial ring where they are abruptly adaxially directed. The tip of the axis remains distant from the posterior edge; the length of the post-axial field equals the length of the first axial ring (sag.). The pleural fields are strongly vaulted. Four pleural ribs are clearly distinguishable, marked by deeper pleural furrows and finer interpleural furrows that all die out far inside the posterior margins. Posterior edge thickened below to form a small sub-vertical portion of the pygidial doublure carrying a sculpture of terrace lines.

\section{Trifoliops cronierae sp. nov.} Figure 5N-P

Holotype. - Thoracopygon, UM-IP 723, Fig. 5N-P.

Etymology. - After Catherine Crônier in recognition of her work on Famennian phacopids in SW Algeria.

Type horizon. - Shale with calcareous concretions of the "Argiles de Marhouma" Formation (member 2a of Crônier et al. 2013), Early rhomboidea Zone.

Type locality. - Marhouma S section, locality 2, South of Marhouma village at $25 \mathrm{~km} \mathrm{~W}$ of Beni Abbes, SW Algeria.

Material. - Holotype specimen UM-IP 723.

Diagnosis. - Pygidium of trapezoidal outline framed behind by small marginal rim; axis conical, pointed behind, with 6 forwards curved axial rings, triangular, keeled end-piece; broad, sub-vertical external doublure.

Description. - Axis of thorax high, evenly vaulted transversely, twice as wide as inner pleural field between axial furrow and fulcrum, very slightly tapering behind. Axial rings robust, straight, deeply notched at distal anterior edges. Pleural and interpleural furrows profoundly marked. Posterior pleural bands twice as long (exsag.) than anterior ones, semi-cylindrical in section inside fulcrum, progressively flattening outside. Pygidium trapezoidal with length, measured between adaxial anterior margin and posterior edge (exsag.), to width index equals 0.38 . Posterior margin very widely curved, slightly embayed medially. Axis conical, of moderate transverse vault, inconspicuously downcurved behind in lateral view. Axial furrows straight, strongly tapering, fading away before reaching tip of axis. Six axial rings in front of end-piece, markedly decreasing 
in length (sag.) from front to rear, forwards curved medially, moderately vaulted in section. Inter-ring furrows continuous, of moderate depth medially, deepening adaxially when approaching axial furrows. Anterior three inter-ring furrows progressively enlarged abaxially and rather deeply notched before meeting axial furrows. End-piece triangular, slightly inflated, keeled longitudinally, pointed behind, remaining in rather short distance from posterior edge of pygidium. Pleural field with five clearly perceptible pleural ribs defined by well-marked, thin interpleural furrows and subdivided into semi-cylindrically shaped pleural bands by rather wide and deep pleural furrows. Posterior pleural bands higher and a little larger (exsag.) than anterior ones. Pleural and interpleural furrows dying out before reaching posterior edge of pygidium, the latter extending further distally than the former. Pleural field framed by a marginal rim on top of vertically descending doublure. Posterior margin of pygidium roof-like upraised medially in posterior view. Entire exoskeleton covered with very fine granules becoming coarser on axial rings. Surface of doublure densely sculptured with coarse granules.

Remarks. - The specimen is almost identical with the undetermined thoracopygon MUA/1094/005 (Crônier et al. 2013, fig. 6m-o) from the Famennian IV-V of Zereg. The axis, though damaged at is posterior end, seems to be shorter, and more material is needed to assess its possible assignment to the new species. However, the important difference in age between both specimens is problematic. The single slightly crashed pygidium from Causses-et-Veyran in the Montagne Noire (Crônier 2003, fig. 6H) is closely related to the new species. Both share the general outline with wide medially slightly embayed posterior margin in addition to the conical axis with laterally deeply notched inter-ring furrows, though the Algerian species is longer and has more axial rings and pleurae. Striking similarities constitute the marginal rim and the broad vertical doublure that are developed nearly identically in both specimens and also in the thoracopygon from Zereg. The latter feature is obviously related to the development of enlarged vincular furrows in Trifoliops. The pygidium from the Montagne Noire was originally assigned to $T$. nigritus by Crônier
(2003); it is now considered constituting the pygidium of $T$. trifolius after the recovery of an entire articulated carcass specimen of $T$. nigritus exhibiting a different pygidium (Crônier et al. 2013). However, the Montagne Noire specimen seems to differ from the type species of Trifoliops by its longer, conical axis with deeply pitted anterior inter-ring furrows, the elevated marginal rim and the broader vertical portion of the doublure. The cephala exhibit ocular protuberances on the anterior genal angle, which are not developed in the type species (Osmólska 1963, p. 508). The material from the Montagne Noire may therefore belong to a different species, which has to be assessed after the discovery of more pygidia.

\section{Genus Dianops Richter \& Richter, 1923}

Type species. - Phacops limbatus Richter, 1848, Famennian V-VI, Saalfeld, Thuringia.

Species assigned. - See most recent assignments in Crônier et al. (2013, p. 1012).

\section{Dianops cf. algeriensis Crônier, 2013 \\ Figure $5 \mathrm{~K}-\mathrm{M}$}

New material. - A single fragmentary counterpart (internal mould) of cephalon, UM-IP 724; 2 exfoliated thoracopyga, UM-IP 725-726, from reddish marlstones, Marhouma S section, locality 4, member 3c of "Argiles de Marhouma Formation" (Crônier et al. 2013), Famennian IV.

Remarks. - The fragmentary cephalon exhibiting a very narrow composite glabellar lobe belongs probably to Dianops algeriensis Crônier, 2013. Associated pygidia are short, lens-shaped (length/width ratio, without articulating half ring, equals 0.3 ) and have a wide, parabolic posterior outline. The axis is low, narrow, of straight descending lateral profile, merging with postaxial field shortly before reaching posterior edge. Only the first axial ring is prominent, the following 4 are lower and vaguely discernable. The pleural fields are only slightly vaulted adaxially. There

Figure 5. A-D - Enigmapyge marhoumensis gen. nov. et sp. nov., "Argiles de Marhouma" Formation, member 2a of Crônier et al. (2013), lower rhomboidea Zone, locality 2, Marhouma S section, SW Algeria. • A-D - holotype, dorsal (A), posterior (B), lateral (D) views of pygidium; dorsal view of entire articulated carapace (C), UM-IP 727. • E-J - Trifoliops trifolius (Osmólska, 1958), "Argiles de Marhouma” Formation, member 2a of Crônier et al. (2013), lower rhomboidea Zone, locality 2, Marhouma S section, SW Algeria. • E, I, J - dorsal (E), lateral (I) and oblique antero-lateral (J) views of cephalon, UM-IP 722. • F-H - dorsal (F), posterior (G) and lateral (H) views of pygidium, UM-IP 723 . $・$ K-M - Dianops cf. algeriensis Crônier et al., 2013, "Argiles de Marhouma” Formation, member 2c of Crônier et al. (2013), Famennian IV, locality 4, Marhouma S section, SW Algeria. • K - dorsal view of thoracopygon, UM-IP 725. • L - dorsal view of thoracopygon, UM-IP 726. • M - dorsal view of internal mould of fragmentary cephalon, UM-IP 724. • N-P - Trifoliops cronierae sp. nov., "Argiles de Marhouma” Formation, member 2a of Crônier et al. (2013), lower rhomboidea Zone, locality 2, Marhouma S section, SW Algeria; dorsal view of thoracopygon (N), dorsal (O) and posterior (P) views of pygidium, UM-IP 723. Scale bars represent $2 \mathrm{~mm}$. 
Raimund Feist et al. • New Late Devonian phacopid trilobites from Marhouma, SW Algerian Sahara
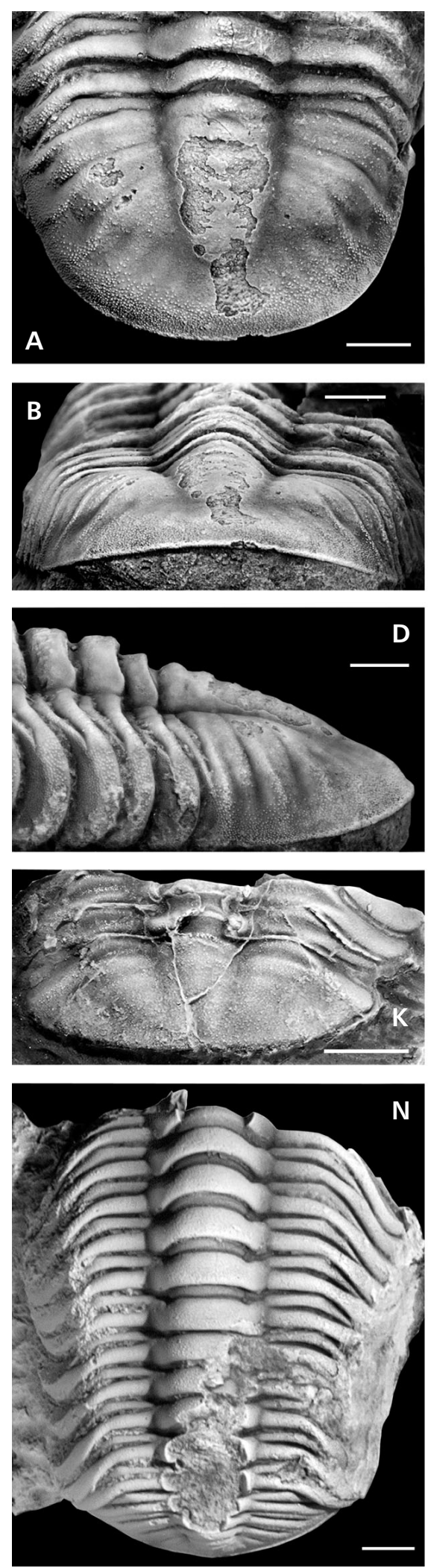
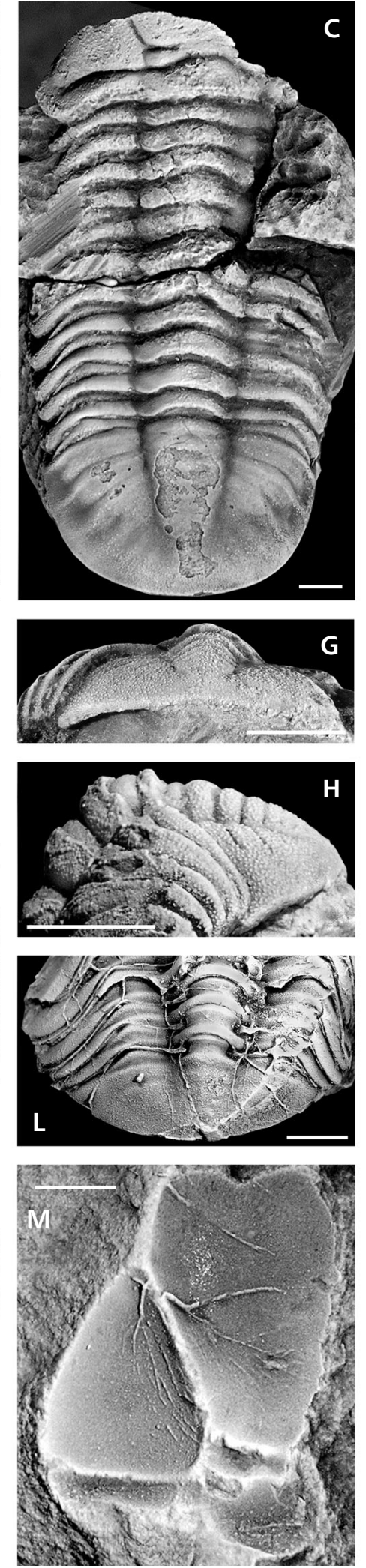
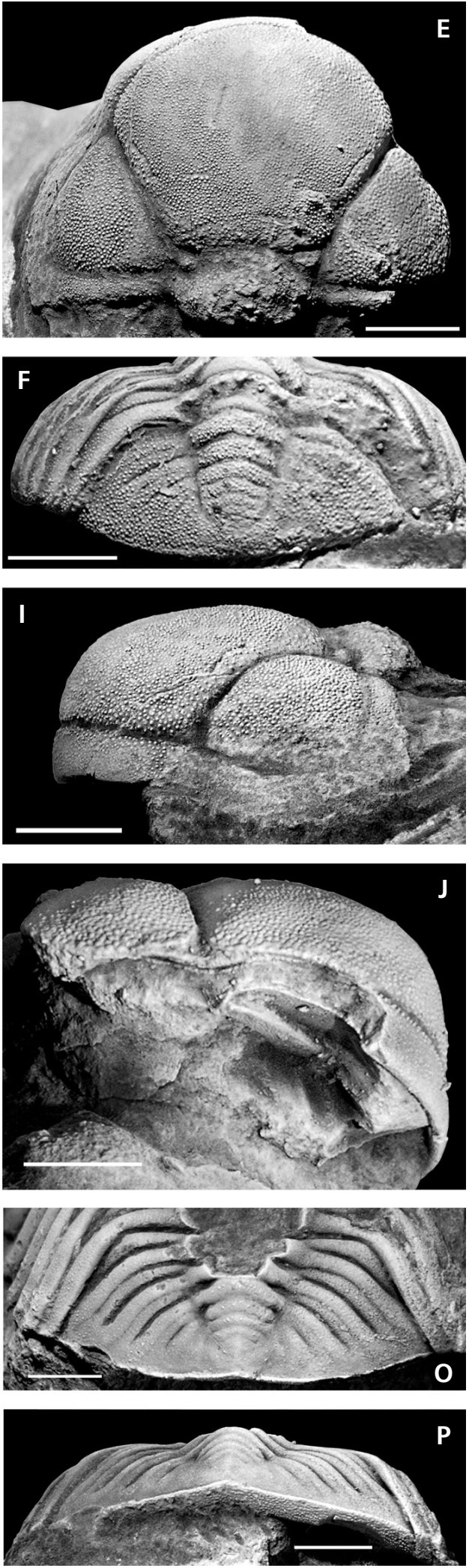
are three low pleural ribs that do not expand to the posterior margin. Known pygidia from Dianops species are all longer (sag.) and have a lesser transverse width.

\section{Genus Enigmapyge gen. nov.}

Type species. - Enigmapyge marhoumensis gen. et sp. nov.

Etymology. - After enigma (Greek) = enigma and pyge $($ Greek $)=$ tail

Species assigned. - Type species only.

Diagnosis. - Cephalon with transverse lateral nodes of L1, medially effaced S1. Pygidium very long, of narrow parabolic posterior outline, with maximum width within anterior third of length; axis long, slender, remaining far from posterior edge; pleural region with individually vaulted posterior border region; pleurae split into short anterior bands and significantly longer posterior bands reaching lateral edges.

Stratigraphical range. - Early Famennian.

Remarks. - The configuration of cephalic features such as the glabellar furrows and the forwards expanding composite lobe, and the thorax with 11 segments doubtless assign the new taxon to the Phacopidae. However, the particular configuration of the long pygidium with pleurae split into a shorter anterior and a narrower, much longer posterior pleural band are likewise not seen in any other phacopid and as such justify its assignment to the new genus.

Occurrence. - SW Algeria (Marhouma region)

\section{Enigmapyge marhoumensis sp. nov.} Figure 5A-D

Holotype. - Entire, articulated exoskeleton with incomplete anterior cephalon, UM-IP 727, Fig. 5A-D.

Etymology. - After Marhouma village, at $30 \mathrm{~km}$ E of Beni Abbes, SW Algeria.

Type horizon. - Shale with calcareous concretions of the "Argiles de Marhouma" Formation (member 2a of Crônier et al. 2013), Early rhomboidea Zone.

Type locality. - Marhouma S section, locality 2, S of Marhouma village at $25 \mathrm{~km} \mathrm{~W}$ of Beni Abbes, SW Algeria.

Material. - Holotype specimen only.
Diagnosis. - As for genus.

Description. - Anterior cephalon broken off. Remaining part of posterior composite glabella lobe not inflated. L1 narrow medially, fused with composite lobe. Lateral nodes of L1 long (exsag.), not inflated, trapezoidal, elongated and slightly vaulted transversely. S1 effaced medially, laterally forming deeply incised almost straight apodemes. Occipital furrow sinuous, deep, forwardly convex between occipital apodemes. Occipital ring wider (tr.) and on higher level than posterior composite glabellar lobe, flat-topped, markedly enlarged medially when strongly curving forwards, straight along posterior edge. Posterior genal field not inflated, moderately vaulted transversely, separated from postero-lateral border by very shallow border furrow at genal angle. Posterior border furrow straight, dying out before reaching genal angle. Posterior border higher than genal field, obliquely crested. Thorax with 11 segments. Axis slightly tapering rearwards. Axial rings of even length (sag.), forwards curved, slightly expanding backwards abaxially, not inflated, flat-topped, with un-notched anterior edges and sinuous posterior edges. Lateral axial lobes or swellings absent. Width (tr.) of adaxial horizontal portion of pleurae equals width of axis. Profile of outer pleurae steeply, almost vertically down-flexed. Pygidium of long elliptical posterior outline; length/width ratio (without articulating half ring) equals 0.66 . Projection of maximum transverse width positioned in anterior third of pygidial length, crossing third axial ring. Axis long, slender, low, with straight descending lateral profile, remaining in considerable distance from posterior edge of pygidium. Axial furrows well marked, slowly tapering. Posterior outline of axis rounded, merging with vaguely vaulted short post-axial ridge. Eight $(+1)$ flat axial rings, the anterior ones insignificantly inflated medially. Pleural region markedly subdivided into an anterior, abaxially strongly down-flexed part, and a much lower posterior part with individualised vault (sag., exsag.) taking the form of a large border region; border defined against anterior part by pronounced break in slope resulting in a curved depression around the posterior tip of the axis. Border is widest behind axis, progressively narrowing until obsolescence at pygidial angles. Pleural field with 6 pleural ribs split into lower and shorter anterior and higher, markedly abaxially extending posterior bands. Anterior bands narrowest (exsag.) at axial furrow, becoming progressively wider and more inflated distally, dying out at depression of break in slope without reaching border. Posterior bands vaguely roof-like in section adaxially becoming progressively crested when extending without change in width and height across border depression and border as far as postero-lateral edges of pygidium. Sculpture: peripherical parts of exoskeleton and medial occipital and axial rings densely tuberculated, sparse tuberculation elsewhere. 
Remarks. - Unfortunately the anterior part of the cephalon is missing and nothing can be said about the presence or absence of the eye lobe and the visual surface. The configurations of L1, the lateral nodes and apodemes in particular, resemble species of Dianops Richter \& Richter, 1923 such as D. typhlops (Gürich, 1896) and species of Dienstina Richter \& Richter, 1931. In all these cases, however, the pygidia are much shorter and the pleural ribs of equal length.

\section{Discussion}

It is striking that Late Devonian trilobite associations in the Saoura region are exclusively composed of phacopid taxa whereas proetids are virtually absent: only a single indeterminable fragment of a cyrtosymboline pygidium was found by us in a body chamber of a late early Famennian cephalopod. Taking into account occurrences of Acuticryphops acuticeps from the late Frasnian of Ben Zireg (Mahboubi et al. 2015), Phacops granulatus (Menchikoff 1930) and Rabinops wedekindi (Malti et al. 2015) from the latest Famennian of Ouarourout, phacopids with 17 determined species in 8 genera have become relatively numerous and diversified in the SW Algerian Sahara region. In contrast, very few Late Devonian phacopids were hitherto being described from the neighbouring Tafilalt region: Phacops erfoudensis Richter \& Richter, 1943 from the Frasnian; Phacops (Phacops) tafilaltensis Crônier \& Clarkson, 2001 and Trimerocephalus lelievrei Crônier \& Feist, 1997 from the Famennian. None of these occur in the Saoura region. Conversely, Omegops accipitrinus (Phillips, 1841) reported from Erfoud by Alberti (1972), and Omegops sp. from Ouidane Chebbi at the eastern border of the Tafilalt basin by Belka et al. (1999) might be conspecific with Omegops bergicus (Drevermann, 1902) from the latest Famennian at Khorb el Ethel (Menchikoff 1930). Besides topmost Famennian records of normally oculated phacopids from shallower environment related to the terminal Famennian regression (e.g. Conrad et al. 1986, Ouali Mehadji et al. 2012), $90 \%$ of early and middle Famennian phacopids represent blind or reduced-eyed taxa whereas, in the Frasnian, reduced-eyed forms prevail. These trilobite associations indicate an offshore level-bottom pelagic environment beyond or at the limit of light penetration. According to Crônier \& François (2014) the bathymetric distribution of these trilobites is in the lower offshore below storm-base, estimated at more than 50-60 m of depth. Taking into account the prevalence of blind trilobites that characterise the "Argiles de Marhouma" Formation, the depositional environment might have been deeper than previously admitted in the Marhouma area (Benhamou et al. 2004). Crônier \& François (2014) have analysed that deeper outer-shelf associations are widespread in the cephalopod limestone realm between the epicontinental margins of Laurussia and Gondwana including interposed terranes of Gondwanan origin. The Algerian phacopids are closely related to contemporaneous faunas in equivalent facies, e.g. Holy Cross Mts ( 5 genera and 5 species in common), Thuringia (4 genera, 3 species), Rhenish Slate Mts (7 genera, 5 species), Montagne Noire (4 genera, 4 species), Iran (3 genera, 2 species). This may indicate that hermetic ocean barriers for migration of benthic biotas such as phacopid trilobites did not exist between Gondwana and Laurussia in Late Devonian times.

\section{Acknowledgements}

This paper benefitted from the expert help of Ralph Thomas Becker (Münster) in determining goniatites, of Carlo Corradini (Cagliari) in determining Famennian conodonts, and of Jana Anger (Frankfurt) in providing casts of originals held in the collections of the Senckenberg Museum. We are grateful to Mohamed Mahboubi and Mohamed El Hadj (Oran) for organising the field campaign and for their efficient assistance. We thank Brigitte Meyer-Berthaud and Jean-Jacques Cornée (Montpellier) for their help in the field. We are greatly indebted to Brian Chatterton (Edmonton) and Catherine Crônier (Lille) for their thorough reviews of the manuscript. This is a contribution of UMR 5554, Montpellier (ISEM 2016-097 SUD).

\section{References}

AlberTI, G.K.B. 1970. Zur Augenreduktion bei devonischen Trilobiten mit Beschreibung von Nephranops franconicus n. sp. aus dem Oberdevon I $\alpha$ von Oberfranken. Paläontologische Zeitschrift 44(3/4), 145-160. DOI 10.1007/BF02990634

Alberti, G.K.B. 1983. Trilobiten des jüngeren Siluriums sowie des Unter- und Mittel-Devons. IV. Senckenbergiana lethaea 64(1), 1-88.

Alberti, H. 1972. Ontogenie des Trilobiten Phacops accipitrinus. Neues Jahrbuch für Geologie und Palaeontologie, Abhandlungen 141(1), 1-36.

Arbizu, M. 1985. Trilobites Phacopinae de la Formación Vidrieros, en el área de Gildar-Montó (León, NO de España) y su distributión estratigráfica. Trabajos de Geologia, Universidad de Oviedo 15, 67-75.

Basse, M. 1998. Trilobiten aus mittlerem Devon des Rhenohercynikums; III. Proetida (3), Phacopida (2), Lichida (Lichoidea, Odontopleuroidea) und ergänzende Daten. Palaeontographica A 249, 1-162.

Becker, R.T. 1993. Stratigraphische Gliederung und Amonoideen-Faunen im Nehdenium (Oberdevon II) von Europa und Nordafrika. Courier Forschungsinstitut Senckenberg 155, $1-405$.

Becker, R.T. \& Schreiber, G. 1994. Zur Trilobiten-Stratigraphie im Letmather Famennium (nördliches Rheinisches Schiefer- 
gebirge). Berliner geowissenschaftliche Abhandlungen E 13, 369-387.

Belka, Z., Klug, C., Kaufmann, B., Korn, D., Döring, S., Feist, R. \& WeNDT, J. 1999. Devonian conodont and ammonoid succession of the eastern Tafilalt (Ouidane Chebbi section), Anti-Atlas, Morocco. Acta Geologica Polonica 49(1), 1-23.

Benhamou, M., Abbache, A., Elmi, S., Mekahli, L., RacheBoeuf, P., Ouali-Mehadj, A. \& Boumendjel, K. 2004. Les calcaires "griottes" et faciès associés du Dévonien supérieur des environs de Beni Abbes au Djebel Heche (Saoura, Algérie): environnements et implications paléogéographiques. Bulletin du Service Géologique d'Algérie 15, 27-49.

Berkowski, B. 1991. A blind phacopid trilobite from the Famennian of the Holy Cross Mountains. Acta Palaeontologica Polonica 36, 255-264.

Boumendjel, K., Morzadec, P., Paris, F. \& Plusquellec, Y. 1997. Le Dévonien de l'Ougarta (Sahara occidental, Algérie). Annales de la Société Géologique du Nord 5, 105-108.

Branson, E.B. \& Meht, M.G. 1934. Conodont Studies. University of Montana Studies 4, 265-344.

Conrad, J., Massa, D. \& Weyant, M. 1986. Late Devonian regression and Early Carboniferous transgression on the Northern African Platform. Annales de la Société géologique de Belgique 109, 113-122.

ChlupáČ, I. 1961. Preliminary report on some new Upper Devonian trilobites from the Moravian Karst. Věstník Ústředního ústavu geologického 36, 477-481.

ChlupÁč, I. 1966. The Upper Devonian and Lower Carboniferous Trilobites of the Moravian Karst. Sborník geologických věd 7, 5-143.

Chlupéč, I. 1971. New phacopid trilobites from the Devonian of Czechoslovakia. Časopis pro mineralogii a geologii 16, 255-261.

CHLuPÁČ, I. 1977. The phacopid trilobites of the Silurian and Devonian of Czechoslovakia. Rozpravy Ústředního ústavu geologického 43, 1-172.

CoRRADINI, C. 1998. Famennian conodonts from two sections near Villasalto. Giornale di Geologia 60, special issue, 122-135.

CrôNIER, C. 2003. Systematic relatioships of the blind phacopine trilobite Trimerocephalus, with a new species from Causses-et-Veyran, Montagne Noire. Acta Palaeontologica Polonica 48(1), 55-70.

CRÔNIER, C. \& ClaRkson, E.N.K. 2001. Variation of eye-lens distribution in a new late Devonian phacopid trilobite. Transactions of the Royal Society of Edinburgh, Earth Sciences 92, 103-113. DOI 10.1017/S0263593300000079

CrônIER, C. \& FeIST, R. 1997. Morphologie et évolution ontogénétique de Trimerocephalus lelievrei nov. sp., premier trilobite phacopidé aveugle du Famennian nord-africain. Geobios (Mémoire spécial 20), 161-170.

CrônIer, C. \& FrançoIs, A. 2014. Distribution patterns of Upper Devonian phacopid trilobites: paleobiogeographic and paleoenvironmental significance. Palaeogeography, Palaeoclimatology, Palaeoecology 404, 12-23.

DOI 10.1016/j.palaeo.2014.03.037
Crônier, C., Malti, F.Z., François, A., Benyoucef, M. \& Brice, D. 2013. First occurrence of a phacopid trilobite faunule from the Upper Devonian of Saoura Valley, Algeria and biodiversity fluctuations. Geological Magazine 150(6), 1007-1021.

Drevermann, F. 1902. Ueber eine Vertretung der EtroeungtStufe auf der rechten Rheinseite. Zeitschrift der Deutschen geologischen Gesellschaft 54, 480-524.

Feist, R. \& Becker, R.T. 1997. Discovery of Famennian trilobites in Australia (Late Devonian, Canning Basin, NW Australia). Geobios (Mémoire spécial 20), 231-242.

Feist, R., McNamara, K.J., Crônier, C. \& Lerosey-Aubril, R. 2009. Patterns of extinction and recovery of phacopid trilobites during the Frasnian-Famennian (Late Devonian) mass extinction event, Canning Basin, Western Australia. Geological Magazine 146(1), 12-33.

DOI 10.1017/S0016756808005335

Feist, R. \& Schindler, E. 1994. Trilobites during the Frasnian Kellwasser Crisis in European Late Devonian cephalopod limestones. Courier Forschungs-Institut Senckenberg 169, 195-223.

Feist, R., Yasdi, M. \& Becker, R. T. 2003. Famennian trilobites from the Shotori Range, E - Iran. Annales de la Société géologique du Nord 10, 285-295.

Glenister, B.F. 1958. Upper Devonian ammonoids from the "Manticoceras" Zone, Fitzroy Basin, Western Australia. Journal of Paleontology 32, 58-96.

GöDDERTZ, B. 1987. Devonische Goniatiten aus SW-Algerien und ihre stratigraphische Einordnung in die ConodontenAbfolge. Palaeontographica A 197, 127-220.

GÜRICH, G. 1896. Das Palaeozoicum im Polnischen Mittelgebirge. Verhandlungen der Russisch-Kaiserlichen Mineralogischen Gesellschaft 32, 1-539.

Hawle, I. \& Corda, A.J.C. 1847. Prodrom einer Monographie der böhmischen Trilobiten. 176 pp. J.G. Calve'sche Buchhandlung, Prague.

Holloway, D.J. 2005. The trilobite genera Eocryphops and Plagiolaria (Phacopidae). Paläontologische Zeitschrift 79(2), 227-239. DOI 10.1007/BF02990186

Holzapfel, E. 1895. Das Obere Mitteldevon (Schichten mit Stringocephalus Burtini und Maeneceras terebratum) im Rheinischen Gebirge. Abhandlungen der Preussischen geologischen Landesanstalt, neue Folge 16, 1-459.

Kaiser, S.I., Becker, R.T. \& El Hassani, A. 2007. Middle to Late Famennian successions at Ain Jemaa (Moroccan Meseta). Implications for regional correlation, event stratigraphy and synsedimentary tectonics of NW Gondwana, 237-260. In BeCker, R.T. \& Kirchgasser, W.T. (eds) Devonian Events and Correlations. Geological Society of London, Special Publication 278.

KEGEL, W. 1931. Über Trilobiten aus dem pelagischen Unter- und Mitteldevon. Jahrbuch der Preussischen geologischen Landesanstalt und Bergakademie zu Berlin 52, 257-283.

Kin, A. \& BŁażejowski, B. 2013. A new Trimerocephalus species (Trilobita, Phacopidae) from the Late Devonian (Early Famennian) of Poland. Zootaxa 3626(3), 345-355.

DOI 10.11646/zootaxa.3626.3.3 
LÜTKE, F. 1968. Trilobiten aus dem Oberdevon des SüdwestHarzes - Stratigraphie, Biotop und Systematik. Senckenbergiana lethaea 49(2/3), 119-191.

Mahboubi, A. 2015. Microfaunes (conodontes, foraminifères) et environnement au Dévonien supérieur du Sahara algérien nord-occidental. 168 pp. Doctorate thesis, University of Montpellier.

Mahboubi, A., Feist, R., Cornée, J.-J., Ouali Mehadji, A. \& GiRARD, C. 2015. Frasnian (Late Devonian) conodonts and environment at the northern margin of the Algerian Sahara platform: the Ben Zireg section. Geological Magazine 152(5), 844-857. DOI 10.1017/S0016756814000715

Mahboubi, A. \& Gatovsky, Y. 2015. Late Devonian conodonts and event stratigraphy in northwestern Algerian Sahara. Journal of African Earth Sciences 101, 322-332.

DOI 10.1016/j.jafrearsci.2014.10.004

Maksimova, Z.A. 1955. Trilobity srednogo i verchnego devona Urala i severnych Mugodzar. Trudy Vsesoyuzhnogo nauchnoissledovatelskogo geologicheskogo instituta, N.S. 3, 1-263.

Malti, F.Z., Benyoucef, M., SAmar, L. \& Sid Houm, R. 2015. The Devonian-Carboniferous boundary in the Saoura Valley (western Algerian Sahara). Strata 16, série 1: communications, IGCP-SDS Symposium, Brussels, September 2015, 89-90.

MAtern, H. 1927. Mitteilungen über die Oberdevon-Fauna der Dill-Mulde. Senckenbergiana 9(6), 252-260.

Matern, H. 1931. Das Oberdevon der Dill-Mulde. Abhandlungen der Preussischen geologischen Landesanstalt, neue Folge 134, 1-139.

McCoy, F. 1849. On the classification of some British fossil Crustacea with notices of new forms in the university collection at Cambridge. Annals and Magazine of Natural History 2, 392-414. DOI 10.1080/03745486009494858

MeIschner, D. 1965. Neue Trilobiten aus dem Devon des Kellerwaldes. Fortschritte de Geologie in Rheinland und Westfalen 9, 119-150.

Menchikoff, N. 1930. Recherches géologiques et morphologiques dans le Nord du Sahara occidental. Revue de géographie physique et de géologie dynamique 3, 103-247.

MüLlER, K.J. 1956. Cephalopodenfauna und Stratigraphie des Oberdevon von Schleiz und Zeulenroda in Thüringen. Beiheft Geologisches Jahrbuch 20, 1-93.

OsmólSKA, H. 1958. Famennian Phacopidae from the Holy Cross Mountains (Poland). Acta Palaeontologica Polonica 3, 119-148.

OsmólsKa, H. 1963. On some Famennian Phacopidae (Trilobita) from the Holy Cross Mountains (Poland). Acta Palaeontologica Polonica 8, 495-523.
Ouali Mehadj, A., Bendella, M., Atif, K., Belkacemi, K. \& Aвbache, A. 2012. Estimation de l'épaisseur réelle et des environnements de depots d'âge Famennian (Dévonien supérieur) de la région de Marhouma (Saoura, Sahara Nord-Ouest, Algérie). Bulletin du Service Géologique National 23, 3-27.

PfeifFER, H. 1954. Der Bohlen bei Saalfeld/Thür. Beiheft zur Zeitschrift Geologie 11, 1-105.

Pfeiffer, H. 1959. Neue Beobachtungen und Funde aus dem Saalfelder Oberdevon. Geologie 8, 262-279.

RichteR, R. 1848. Beitrag zur Paläontologie des Thüringer Waldes. Die Grauwacke des Bohlens und des Pfaffenbergs bei Saalfeld. I. Fauna. 48 pp. Arnoldi, Dresden \& Leipzig.

RichteR, R. 1856. Beiträge zur Paläontologie des Thüringer Waldes. Erster Theil. Denkschriften der Kaiserlichen Akademie der Wissenschaften, Mathematisch-naturwissenschaftliche Klasse 11, 87-138.

RichteR, R. \& RichtER, E. 1923. Systematik und Stratigraphie der Oberdevon-Trilobiten des Ostthüringischen Schiefergebirges. Senckenbergiana 5, 59-76.

Richter, R. \& RichteR, E. 1926. Beiträge zur Kenntnis devonischer Trilobiten. IV. Die Trilobiten des Oberdevon. Abhandlungen der Preussischen geologischen Landesanstalt, neue Folge 99, 1-314.

Richter, R. \& Richter, E. 1931. Unterlagen zum Fossilium Catalogus, Trilobitae. V. Senckenbergiana 13, 140-146.

Richter, R. \& RichteR, E. 1943. Trilobiten aus dem Devon von Marokko. Senckenbergiana 26(1/3), 116-199.

Richter, R. \& Richter, E. 1955. Oberdevonische Trilobiten, Nachträge. 1. Trilobiten aus der Prolobites-Stufe III. 2. Phylogenie der oberdevonischen Phacopidae. Senckenbergiana lethaea 36(1/2), 49-72.

SAnnemanN, D. 1955. Beitrag zur Untergliederung des Oberdevons nach Conodonten. Neues Jahrbuch für Geologie und Paläontologie, Abhandlungen 100, 324-331.

Weyer, D., Feist, R. \& Girard, C. 2003. Conodonts, Trilobita, and Anthozoa near the Late Frasnian Upper Kellwasser Event of the Geipel Quarry section in Schleiz, Thuringian Mountains (Germany). Mitteilungen des Museums für Naturkunde, Berlin, Geowissenschaftliche Reihe 6, 71-78.

Whittington, H.B. \& Kelly, S.R.A. 1997. Morphological terms applied to Trilobita, 313-329. In KAESLER, R.L. (ed.) Treatise on Invertebrate Paleontology, part O. Arthropoda 1. Trilobita, revised, 1: Introduction, Order Agnostida, Order Redlichiida. xxiv +530 pp. Geological Society of America \& University of Kansas Press, Boulder \& Lawrence. 